\title{
Merkel Cell Carcinoma TNM Finding v7
}

National Cancer Institute

\section{Source}

National Cancer Institute. Merkel Cell Carcinoma TNM Finding v7. NCI Thesaurus. Code C88497.

A finding about one or more characteristics of Merkel cell carcinoma, following the rules of the TNM AJCC v7 classification system. (from AJCC 7th Ed.) 